|||||||||||||||||||||||||||||||||||||

総合報告

․ㅔ․
表面と真空 Vol. 61, No. 1, pp. 39-40, 2018

特集「学会誌合併創刊号一過去を振り返り, 未来を共に歩む一」

https://doi.org/10.1380/vss.61.39

\title{
真空装置メーカーにおける学会活動の歩みと新学会の将来への期待
}

\author{
齋 藤 一 也* \\ 株式会社アルバック 寀253-8543 茅ケ崎市萩園 2500 \\ （2017 年 11 月 13 日受付；2017 年 12 月 5 日掲載決定）
}

\section{Overview on the Vacuum System Maker's Society Activities and Expectations for New Academic Society \\ Kazuya SAITO*}

ULVAC, Inc., 2500 Hagisono, Chigasaki, Kanagawa 253-8543

(Received November 13, 2017 ; Accepted December 5, 2017)

\begin{abstract}
I overview ULVAC's activities and developments in the Vacuum Society of Japan in past, and give congratulatory message for new academic society.
\end{abstract}

KEYWORDS : Vacuum technology, Surface science

\section{1.は じめに}

日本真空学会と日本表面科学会が統合し, 新たな日本 表面真空学会としての活動が始まる記念すべき「合併創 刊号」に投稿させていただき, 誠に光栄に存じます。心 からお祝い申し上げます。

私共アルバックは, 日本真空学会（旧日本真空協会） 設立当初より, 本学会および日本真空工業会の一員とし て参画させていただいてきました。本稿では, 今までの 歩みを振り返り, 今後の真空・表面科学に関する学会・ 企業の活動について考えてみたいと思います。

\section{2. アルバックと日本真空学会}

日本真空学会の前身の真空協会創立と弊社アルバック (旧日本真空技術株式会社) の創業は, それぞれ 1958 年 と 1952 年であり, 創立前の真空研究会まで含めるとほ ぼ時を同じくして誕生した。戦後の復興期に日本の未来 を信じ, 将来の産業基盤となる真空技術を発展させるこ とを目的とし, 大学・研究機関とメーカーが一体となっ て相補的に機能するよう運営されてきた。メーカーであ るアルバックの生い立ちに関しても言及すると, 井街仁 (第 2 代社長) は「金銭的富の獲得を期してはじめるの

\footnotetext{
*E-mail : kazuya_saitou@ulvac.com
}

が資本主義社会のベンチャーと言うのであれば，この会 社の設立の動機は少し違っていた。と表現され，幕末 の志士の魂とキリスト教的な博愛精神を併せ持っていた と説明されたのが印象的であった。弊社だけでなく，当 時設立された会社の多くは，同じ思いを共有していたの だろうと考える。

それからの約 60 年間を日本真空学会と弊社は共に歩 んできた。前述の井街仁社長（当時）は歴代最長の 10 年間会長を務め, 第 3 代社長の林主税も理事として通算 18 年間務めた。この抒二人以外にも辻泰（元アルバッ クコーポレートセンター取締役, 東京大学名誉教授), 塚原園子（元超材料研究所所長）を含む多くの先輩方が 学会理事, 委員を務めた。現在でもアルバックは, 諸先 輩方の意思を引き継いで, 個人理事の他, 7つの委員会 ・部会に参加している。

技術的な側面では, 真空装置を構成する材料からのガ ス放出測定方法 (コンダクタンス変調法, 流路切り替え 法, TDS 測定, BET 測定), 真空装置内のガスの挙動測 定 (吸着確率測定, 水素透過測定), 新規低ガス放出表 面処理法などの基盤技術の開発を進めると共に， スパッ タリング成膜技術, 極高真空用電離真空計, 質量分析計 などのコンポーネントに関する応用開発打よび真空計の 校正などに関しての活動を進めてきた。この成果のいく つかは現在の弊社の基盤技術として定着している。 


\section{3. 広がる真空技術・表面科学応用分野}

視点を変えて, 現在のアルバックが関わる真空装置市 場の動向について紹介する。現在, ディスプレイおよび 半導体・電子部品用設備投資は旺盛である。ディスプレ イについては, スマートフォン用の小型高精細ディスプ レイと大型 $4 \mathrm{KTV}$ 向けの量産設備投資が活況で, 液晶か ら OLED への技術転換も大きな真空装置市場を生み出 している。特に小型ディスプレイでは, 大手のスマート フォンに搭載されているフレキシブル OLED に追随し ようとする動きが強い。

電子部品では, スマートフォンに搭載される通信モジ ュールやカメラモジュール, 指紋や 3D 顔認証用のセン サーなど, 従来デバイスの性能向上と新規デバイス搭載 による最終商品の性能競争が新たな装置需要を喚起して いる。

半導体では, ハードディスク置き換え需要のために 3D-NAND（フラッシュメモリ）の大規模な投資が行わ れており，メモリはデータセンターに集まる膨大な情報 の蓄積に使われる。扱われるデータの増大は加速するた め, メモリに対する需要は今後も継続するものと考えら れる。

更に集まったビッグデータを資源にした情報解析によ る新ビジネスが生まれつつあり, 有効に高速に処理する ための AI 活用や量子コンピューター開発が進められて いる。これらの技術が, IoT, ICTを利用したスマート 社会を実現していくものと考えられている。

上述した全てのデバイスの製造工程では, 多くの真空 技術と表面科学が利用されている。ただし, 多くの複雑 なプロセスを駆使した製造工程では, 原理的な解析やキ ヤラクタリゼーションが不十分なものも多い。更に高度 なプロセスを実現していくためには, 精緻な表面・薄膜 ・加工制御技術と分析・解析が必要である。また, 今後 のデバイス構造の複雑化に伴い, 従来の成膜・加工方 法, 材料では実現できない状況も考えられる。メーカー が直面する大きな課題に対しても官学の支援を頂きなが
ら独創的，革新的な表面制御技術の提案・創出してゆき たいと考える。

\section{4. グローバルな交流の促進}

上記のデバイスのメーカーの多くは，既に海外メーカ 一であり，今後も設備投資の主役は海外勢であると考え る。必然今後, 装置メーカーは海外顧客の要求に対応す るために, 技術開発の重心を海外にシフトする必要に迫 られていくものと考えられる。それに伴い, 開発者とし て海外人材採用の割合が増していく。国籍を問わず若い 人材を育て, 真空・表面科学を十分理解した研究者, 技 術者をより多く輩出できるような活動を今以上に活発化 する必要がある。

2022 年に日本で 3 回目の真空に関する国際会議とな る IVC-22 の札棍での開催が決定されている。世界の研 究者と切硣㻟磨し, 新たな時代に挑み, それを楽しむた めの様々なアイデアを盛り込んでいただけたらと思う。

\section{5. お わに}

ノーベル賞で一般に知れ渡った「重力波」であるが, 日本でも今年から岐阜県飛騨市の地下で観測が開始され る。この重力波観測施設「かぐら」は, 長さ $3 \mathrm{~km}$ の真 空ダクト 2 本が L 字形に交わる巨大な真空装置であり, 日本真空学会の前会長である齊藤芳男先生が設備を担当 されている。この施設において，ミラーの間を多重に反 射するレーザー光線が重力波によって僅かな時間のずれ を生じ, これを検知する。

アメリカの「LIGO-Virgo 共同実験」においてアイン シュタインが予測した重力波を観測できることが実証さ れたことだけでも非常に画期的であるが，今後の観測結 果によって発見される宇宙の新事実に期待が膨らむ。

新たな一歩を踏み出す日本表面真空学会が, これから も真空技術・表面科学によって様々な現象を解き明か し，その醍醐味を共有できる仲間の輪を世界へ広げてい かれることを祈念し確信する。 